\title{
A review on surface treatment for concrete - Part 2: performance
}

\author{
Xiaoying $\operatorname{Pan}^{1}$, Zhenguo $\mathrm{Shi}^{2}$, Caijun $\mathrm{Shi}^{1}{ }^{*}$, Tung-Chai Ling ${ }^{1}, \mathrm{Ning} \mathrm{Li}^{1}$
}

\begin{abstract}
There are variety of surface treatments used for concrete structures protection . This paper presents a review of the effect of surface treatments on mechanical properties and durability concrete, and the durability of treatment materials themselves. Several common surface treatment are reviewed, including acrylic coating, polyurethane coating, epoxy coating, silanes, siloxanes sodium silicate, and nano- $\mathrm{SiO}_{2}$. These surface treatments showed different impacts on physical and mechanical properties, water permeability, chloride migration, carbonation resistance, sulphate attack, and freeze-thaw cycle. It is important to consider their strengths and weakness when choosing a surface treatment. In addition, there are limited prediction model for the service-life of treated concretes, though many tests were conducted to measure the barriers properties of these surface treatments. Many of the surface treatments, especially organic treatments, are generally subjected to aging and weathering, and thus the long-term protection cannot be promised. Hence, both the protective effect and long-term durability of the surface treatment should be taken into account in service-life modelling.
\end{abstract}

Keywords: Concrete; Surface treatment; Compressive; Permeability; Durability 


\section{Introduction}

In many cases, the reliability of concrete structures is, determined by durability problems, e.g. carbonation, corrosion of steel bars and sulfate attacks $[1,2]$. The surface layer of concrete which usually refers to a $30 \mathrm{~mm}$ thick layer below the surface affords both physical and chemical protections against ingress of aggressive substances [3-5]. Since many aggressive substances transport through water or air, the permeation characteristics of the surface concrete is an important factor for the durability of whole concrete element [5-8]. Surface treatment is an economical and effective method to improve the quality of surface layer and protect the concrete structure compared with other methods, such as decrease water to cement ratio and add admixtures etc.

There are a variety of surface treatments that can be used for protection of concrete. According to the chemical compositions of the surface treatment agents, the surface treatments can be classified into two groups: inorganic and organic [9-11]. The organic surface treatments have good barrier properties, but their limiting service life has got wide concerns. The inorganic surface treatments are more stable and have better resistance to aging, but limited studies about their application have been published. Surface treatments were grouped into four categories according to functions. (a) Surface coating can form a continuous polymer film and create a physical barrier to suppress the ingress of the aggressive substances [12-14]. Many surface coatings have been using in foundations and quays, e.g. acrylic, butadiene copolymer, chlorinated rubber, epoxy resin, oleoresinous, polyester resin, polyethylene copolymer, polyurethane, vinyl, coal tar and polymer modified mortar [15]. (b) Hydrophobic impregnation is usually performed through silane or siloxane-based water repellent products $[13,16]$. They create a water-repellent pore surface in the surface-near zone and leaves the pores open $[15,17]$. (c) Pore-blocking treatment agents are able to partially or completely fill the capillary pores and thus reduce the porosity of surface layer. Silicate-based pore blockers are the most common products in this group. There are some new generation pore-blocking agents which drew lots of concerns, such as nano- $\mathrm{SiO}_{2}$ and $\mathrm{CaCO}_{3}$ precipitation. Recently there has been an increasing acceptance of pore-blocking treatment materials for protecting buildings and highway bridges [17, 18, 19]. (d) Multifunctional 
surface treatments have at least two functions, such as ethyl silicate and modified clay nanocomposites which cannot only block the capillary pores but also form hydrophobic layer $[11,16,20]$.

This review includes two parts. The first part reviews the classification, mechanism and influencing factors for surface treatments [21]. This second part provide summary and comparison of the effects of surface treatments on concrete properties, and durability of surface treatments. The purpose of this review is to facilitate the successful applications of surface treatment, and some suggestions for further research.

\section{Effect of surface treatment on mechanical and physical properties of concrete}

The effects of surface treatments on the strength of concrete have not attracted much attention. It is widely accepted that most other surface treatments cannot directly improve the strength of concrete because they cannot improve the quality and porosity of the whole concrete element. However, surface treatments are able to prevent the degradation of strength when the concrete is subjected to a fire. According to research of Li [22], the compressive strength of concrete with silicate-based coating enhanced by $3.8 \%, 3.7 \%, 11.0 \%, 17.3 \%$ and $6.1 \%$ compared to uncoated concrete, after being exposed to $150,300,450,600$ and $750{ }^{\circ} \mathrm{C}$. Recently, Yuan et al. [23] also reported that silicate surface treatment could effectively enhance the residual compressive strength and elastic modulus of concrete exposed to temperature from 200 to $700{ }^{\circ} \mathrm{C}$.

The abrasion resistance is a good indicator for evaluation of the longevity of surface-treated concrete under repetitive traffic loadings. Many of surface treatments can improve the abrasive resistance of concrete surface [24-26]. Dang et al. [27] found that most organic surface coatings could improve the abrasion resistance of concrete. Among the organic coatings they investigated, epoxy performed best while methacrylate with high molecular weight showed no protection. A slight enhancement of abrasion resistance was observed for the concrete treated with silanes, because the friction coefficient of concrete surface could be reduced by silanes [16, 27]. Franzoni et al. [11] investigated the effects of some inorganic surface treatments on abrasion resistance. According to their results, the abrasion resistance of surface-treated concrete has the following order: sodium silicate > ethyl 
silicate > nano-silica. Sodium silicate showed best effect because it could form a protective layer with remarkable thickness. Since above researches used different matrixes and testing methods, it is hard to compare the effects of surface treatments in different groups. Thus, some researches need to conduct to further identify the most anti-abrasion surface treatment.

In addition, concrete surface treatments can affect the shrinkage due to changes in the moisture transportation and evaporation rate. However, relatively few researches focused on this area. Shi et al. [28] showed that polymer coating could obviously reduce the mortar drying shrinkage. The thicker the polymer coating was and the earlier the coating was applied, the greater shrinkage reducing ratio was observed, as shown in Fig 1. A thicker polymer coating could form highly compact film on the surface of mortar to seal open capillaries and avoid the moisture dissipation. Thus, it could block more capillary and coarse pores to suppress moisture evaporation, finally reducing more drying shrinkage. When the polymer was coated at a later time, the almost fully developed capillary structure and the low residual moisture in capillary pores caused small remaining shrinkage. Thus, the coating showed less effectiveness. There are not investigation about the effect of hydrophobic and pore-blocking treatment.

\section{Effect of surface treatment on concrete durability}

The protection provided by the surface treatments varied with their physical and chemical properties $[25,29]$. They must fulfill a variety of requirements in order to prolong the service life of concrete structures [30,31]. This section reviews the effects of surface treatments on different durability aspects of concrete.

\subsection{Water permeability}

Since water is essential for many forms of deterioration of concrete, a high resistance to water penetration is an important criteria for surface treatments [32, 33]. The NCHRP Report 244 recommends an acceptance of surface treatments which reduce water absorption by $75 \%$ [34]. The German Committee for Reinforced Concrete specified that a limiting water absorption of $2.5 \%$ by mass and a reduction in water absorption by at least $50 \%$ of the 
untreated concrete should be obtained after treatment, though the rationale behind this is not clear [8].

Many surface coatings are able to reduce the ingress of water through the treated matrix. Epoxy coatings, silane with an acrylic top coat, methyl methacrylate, alkyl alkoxysilane (two coats) and oligomeric siloxane have been found to be very effective in reducing the water uptake of concrete [35]. According to Almusallam et al. [30], the uncoated cement mortars absorbed water at a very rapid rate and the total absorption was about $5 \%$ by weight after $56 \mathrm{~h}$. However, the water absorptions in the cement mortars coated with polymer emulsion, acrylic, chlorinated rubber, polyurethane coatings, and epoxy coatings were in the range of 3.3-3.4\%, $0.23-1.46 \%, 0.76-1.04 \%, 0.21-1.83 \%$, and $0.27-1.3 \%$ respectively. In term of hydrophobic impregnations, Medeiros et al. $[13,36]$ demonstrated that silane and siloxane had the capacity of considerably inhibiting water penetration when water pressure was lower than $120 \mathrm{kgf} / \mathrm{m}^{2}$. The results indicated that hydrophobic surface treatments should only be used when the water exposure conditions are well known. If there is water pressure, this pressure needs to be considered and, in general, another treatment methods are recommended [35]. Franzoni et al. [37] found that the efficiency of ethyl silicate was more significant than those of sodium silicate and nano-silica.

It is difficult to compare the effect of surface treatments on concrete permeability, due to the diversity of concrete matrix used in different researches. Thus, the relative water absorptions of concretes with different surface treatments were compared, as shown in Table 1. The water absorption of untreated concrete is normalized as 1 . The water absorptions of surface-treated specimens have the following order: chlorinated rubber $\approx$ acrylic $\approx$ epoxy resin $\approx$ polyurethane $\approx$ silane/siloxane $>$ fluorinated polymer $>$ ethyl silicate $>$ modified cementitious mortar coating $>$ sodium silicate $\approx$ magnesium fluosilicate $\approx$ polymer emulsion coating > nano-silica. A large variation in the performance of the coatings of the same generic type, procured from different manufacturers, was noted. Hence, it is advised that the selection of a coating for moisture resistance should not base on the sole criterion, but should be tested individually generic type before application. Additionally, there are very few research about the effect of surface treatment on permeability of high performance concrete (HPC) which is more and more common in modern structures. According to results of Weisheit et al. [42], the 
siloxane copolymer could only slightly reduce the water absorption of HPC, and could not prevent the water ingress after weathering. Our previous research [25] on inorganic surface treatments indicated that the inorganic surface treatments had good resistance to ingress of water. The effect of sodium silicate could improve with a sodium fluosilicate pretreatment, and magnesium fluosilicate had similar effect with sodium silicate. Both the magnesium fluosilicate and sodium fluosilicate have potential in field application.

\subsection{Chloride permeability}

There are a number of mechanisms by which chloride transports in concrete, including diffusion under the influence of a concentration gradient, absorption due to a capillary action, migration in an electrical field [6, 43, 44]. Diffusion is the primary mechanism of chloride transport in concrete where there is no electric field and the water saturation in concrete pore structure is stable at $60 \%-70 \%[6,45]$. In most cases, surface treatments can prevent the ingress of chloride ion. Effects of surface treatments on the transport of chloride ion are summarized in Table 2. It is not easy to compare the effect of all these surface treatment on resistance of chloride, because the different testing method. It is widely accepted that polymer coatings are more efficient than other treatment methods in chloride resistance. According to Almusallam et al. [30], the polyurethane and acrylic coatings were about 10 times more effective in resisting the diffusion of chloride ions, compared to the uncoated concrete. The chlorinated rubber coatings were half as effective as the epoxy coatings and the chloride concentration in the concrete coated with the polymer emulsion coatings was $60-70 \%$ of those in the uncoated concrete specimens [30]. However, previous researches cannot get agreement on the effect of silane and silicate based treatment. Buenfeld et al. [44] found showed that chloride diffusion coefficients were one to over three orders of magnitude lower than the untreated mortar after applying silane, polymer-modified cementitious coating, and polyurethane sealer. Dhir [48] showed that the silane was more effective than acrylic coating in preventing chloride ion. Some research showed that silane failed to prevent the diffusion of chloride ion, but could delay the initial time of steady state [8]. On the other hand, Ibrahim et al. [46] reported that the effect of sodium silicate was negligible, while Franzoni [11] stated that chloride migration depth reduced by $30-50 \%$ after sodium silicate treatment. Moon [18] 
also showed calcium silicate could reduce the diffusion of chloride ions though this would be influenced by the number of treatment layer. Our on-going research indicated the difference in previous result might result in different curing condition and time before the chloride diffusion test. Silicate-base treatments need interacting time to react with cementitous substrate to show their effectiveness. Some newly developed treatments, such as ethyl silicate, nanosilica, nanocomposites coatings and bio-deposition of calcium carbonate were also investigated. The nanocomposites coatings generally have better performance than traditional polymer coating [14]. According to Muynck et al. [49] the biodeposition showed similar resistance towards the migration of chlorides as acrylic coating and the water repellent silanes and silicones, and showed higher resistance than in the case of the silanes/siloxanes mixture.

The capacity of surface treatment to protection varies with the categories and environment. Dhir [48] found that resistance of organic surface treatment to chloride ion related to the temperature, because the link within the organic polymer may broke under high temperature. Silane performed best at $35{ }^{\circ} \mathrm{C}$ than higher or lower temperature [8]. Pritzl et al. [50] reported that the relative reduction in $\mathrm{Cl}^{-}$diffusion coefficient was larger when the concrete itself had a higher diffusion coefficient. Yang et al. [51] investigated the chloride penetration of concrete with different w/c ratio and silane dosage, as shown in Fig. 2. The chloride content in concretes with the same dosage of silane increased with w/c ratio. On the other hand, the chloride content decreased with the coverage rate of silaneas for concretes with the same w/c ratio.

Chloride diffusion resistance is difficult to characterize, primarily because chloride ingress into concrete is a complex process [52], and the natural chloride diffusion is extremely slow in a surface-treated concrete [43]. There are essentially two approaches to evaluate the natural chloride diffusion, steady state and unsteady state methods [53]. The steady state (or diffusion cell method) involves installing a thin specimen to separate half cells containing chloride and chloride-free solutions, and monitoring the chloride concentration in the initially chloride-free solution as a function of time, to determine an effective diffusion coefficient [43]. The diffusion cell method has been used widely on cementitious materials, but relative not common on evaluation of effect of surface treatment. On the other hand, the unsteady state, or chloride profile method is widely used in measure the chloride diffusion coefficient 
of surface-treated concrete. In this method, specimens are immersed in a chloride solution for a period of months or years, and then they are analyzed and the resulting chloride profiles compared. For untreated specimens, results can be presented in the form of an apparent diffusion coefficient and a surface chloride content, based on fitting a curve to the profiles complying with the error function solution of Fick's 2nd Law [54]. Based on Fick's 2nd Law, Moradllo et al. [55] proposed a model to describe the time-dependent performance of several kinds of surface treatment on concrete exposed to the tidal zone of Persian Gulf region. Petcherdchoo [56] develop a pseudo-coating model as an improvement of Moradllo's model and got better agreement with experimental date. However, it was reported that the unsteady state was unsound for interpreting chloride profiles in some surface-treated concrete because its assumption of a constant boundary condition at the interface between the surface treatment and substrate [57]. Zhang et al. [57] found that the interfacial concentration of chloride increased with time. Hence the chloride profile in the concrete substrate does not obey Fick's law with a constant concentration boundary condition. If Fick's law is applied to describe a surface-treated concrete, the calculated diffusion coefficient will be less than the actual diffusion coefficient. Schueremans et al. found a dramatically increase of chloride concentration in around $15 \mathrm{~mm}$ depth after surface treatment, while this phenomenon was not observed in the concrete without treatment (Fig. 3) [46, 58-60]. The refinement of a surface chloride profile was used to more accurately predict the rate of chloride ingresses in surface-treated concrete, considering an initial set of surface chloride and the square root model [61]. Therefore, more detailed study of chloride diffusion through surface-treated concrete is still required. Improvements can be made to the existing service life models for reinforced concrete with surface treatment so that they can better represent or simulate the field behavior of these concrete structures and effect of surface treatments.

\subsection{Carbonation}

In urban and industrial areas, environmental pollution results in a significant concentration of carbon dioxide, and thus carbonation-initiated reinforcement corrosion prevails [62-64]. Carbonation is a chemical reaction between $\mathrm{Ca}(\mathrm{OH})_{2}$, calcium-silicate-hydrate $(\mathrm{C}-\mathrm{S}-\mathrm{H})$ and $\mathrm{CO}_{2}$ to form $\mathrm{CaCO}_{3}$, silica-rich $\mathrm{C}-\mathrm{S}-\mathrm{H}$ and amorphous 
silica gel [65], and destroy the passivity of the embedded reinforcement bars [66, 67]. The carbonation process indicates that the factors controlling carbonation are the diffusivity of $\mathrm{CO}_{2}$ and the reactivity of $\mathrm{CO}_{2}$ with the concrete. The diffusivity of $\mathrm{CO}_{2}$ depends on the pore system of hardened concrete and the exposure condition [68].

The carbonation of concrete could be reduced by most surface treatments except silane and siloxane which have been proved to have limited resistance to $\mathrm{CO}_{2}$ [69]. Silane and siloxane can only control the moisture content of the concrete substrate, but they cannot reduce the air permeability, and thus the diffusivity of $\mathrm{CO}_{2}$ of concrete $[8,70]$. It was reported that organic polymer coatings were effective anti-carbonation methods, while the thickness of the coatings should be at least $200 \mu \mathrm{m}$ [8]. According to Park [71], the permeation and diffusion coefficient of carbon dioxide significantly reduced by organic surface coatings. Table 3 summarizes the effects of acrylic coating, silane and several inorganic surface treatments on carbonation depth. It can be seen that the acrylic coating is more effective than other methods. Both sodium silicate and ethyl silicate performed well in early ages, while the ethyl silicate seemed to have better long-term effect [11]. Combined with results of Park and Table 3, the polyvinyl chloride $>$ polyurethane $>$ epoxy $>$ acrylic $>$ sodium silicate $>$ ethyl silicate $>$ calcium silicate $>$ nano-silica $>$ silane $\approx$ siloxane. Aguiar et al. [69] found that the water-cement ratio was very importance even in treated concrete. The unprotected concrete with w/c of 0.6 presented lower carbonation rate than the concretes with w/c of 0.7 and siloxane and acrylic treatments.

There are only a few available carbonation model for surface-treated concrete. Park [71] have constructed a diffusion-reaction carbonation model using the finite element method to estimate the depth of carbonation of concrete with surface coatings. The effects of the degradation of coatings have also been examined in the model. However, this model cannot be used for penetrative surface treatments. The carbonation model for concrete treated with sodium silicate and ethyl silicate should be more complicate because the reaction between the treatment agents and substrate which will alter the porosity, $\mathrm{pH}$, and the boundary resistance $[59,72]$. Since there is no report on the porosity and permeability coefficient of the treated surface, it is difficult to build a realistic model for these surface treatments. 


\subsection{Sulphate attack}

Sulphate attack of concrete can be broadly classified into three types: physical, chemical and microbiological attack $[73,74]$. Sulphate attack is responsible for billions of dollars of damage to concrete wastewater collection and treatment systems throughout the world. Surface treatment systems can improve the resistance of concrete to these sulphate attacks.

The effectiveness of surface treatments on chemical sulphate attack has been studied for a long time. In 1990s, Redner et al. [75, 76] evaluated performance of more than 20 different coating systems in $10 \%$ sulfuric acid. Their test results showed that there were no failures in the coating films after 1 year of immersion. A study by Aguiar et al. [29] indicated that concrete protected by a silicon agent showed poor performance under sulfate attack compared with that of concrete coated with a water based acrylic. Ibrahim et al. [60] reported the ability of six surface treatments on the sulphate resistance. The compressive strength of concrete treated with silane/siloxane with an acrylic topcoat reduced by $0.3 \%$ after about two months of immersion in the sulfate solution and $8.3 \%$ after 330 days immersion. However, strength reductions in the concrete coated with sodium silicate and a silicone resin solution were very small. Their results showed the resistance of the six surface treatments have the following order: silane/siloxane with an acrylic topcoat > two component acrylic topcoat > silane/siloxane $>$ silicone resin > sodium silicate. Vipulanandan and Liu [77] reported that the glass-fiber mat-reinforced epoxy coating extended the lifetime of concrete by over 70 times when immersed in 3\% sulfuric acid. Nia et al [78] showed that polyurethane was more effective and economical than epoxy. Service life increment for $1000 \mu$ thickness for polyurethane is obtained as approximately 14.5 years, while this amount for epoxy is approximately 11 years. Recently, Song et al. [79] used the precursor solution of super-absorbent resin (SAR) to concrete surface treatment, and demonstrated that the SAR would effectively cut the penetration channel of external aggressive sulfate in situ. Based on previous research, organic coatings have better resistance than silane based hydrophobic and sodium silicate. Within the organic coatings, the polyurethane is most effective. However, there is no report about the performance of other newly developed surface treatment systems. Moreover, the $\mathrm{H}_{2} \mathrm{~S}$ concentrations have increased within sewer pipe. Many coatings that 
provided long-term performance and protection in the past have failed within a year or two under high $\mathrm{H}_{2} \mathrm{~S}$ conditions. But there is no research focused on the effect of the volume and pressure of gases on the sulphate attack.

In turn of physical sulfate attack, Suleiman et al. [80] evaluated the effects of several surface treatments. The bitumen coating provides similar protection for high quality concrete to that of epoxy, but the bitumen coating was more likely to separate with substrate which has higher w/c ratio. Because water molecules might entrap between the bitumen coating layer and the substrate when high porosity concrete was coated with bitumen at early age. This generally did not occur for the epoxy based coating which had higher adhesion [81]. Acrylic is a relatively brittle material and may not sustain the strains due to salt crystallization [82]. In summary, the resistance of surface treatments increased in the following order: epoxy, silane, bitumen and water-based solid acrylic.

According to Berndt [73] and Muynck [84], epoxy coating and polyurea lining could prevent biogenic sulfuric acid (BSA) corrosion more effectively than hydrous silicates or antimicrobial compounds. They also stated that the cementitious coating was inadequate in resist BSA. However, these coating methods suffer from several disadvantages [84]: difficult to create proper adhesion due to the difficulty to provide proper surface preparations, the presence of contaminants on the surface; uneven layer thickness which results in an uneven stress loading and subsequent premature failure of the coating.

Vipulanandan and Liu [85-87] carried out extensive research on sulfate corrosion for surface treatment concrete, and developed a prediction model of weight change in coated concrete under sulphate attack. They claimed that the thickness of was a very important factor, and the interface properties may have affected the penetration of liquids. There are some main factors that influence the resistance of sulphate attack on surface treatment concrete $[84,85$, 88]: 1) the higher content of $\mathrm{Ca}(\mathrm{OH})_{2}$ will result in more formation of gypsum, and more expansion; 2) the moisture content in substrate; 3) adhesion between coating and substrate; and 4) the distribution in pinholes which will increase the penetration of $\mathrm{SO}_{4}{ }^{2-}$ significantly.

\subsection{Freeze-thaw resistance}

Although surface treatment cannot be used as alternatives for air-entraining agent in 
protecting concrete from freeze-thaw cycle, it can provide additional protection, especially in the extreme cold environment [27]. Dang et al [27] stated that surface treatments delayed the ingress of moisture during the freeze-thaw condition, thus they increased the time to reach the critical moisture content. Basheer et al. [89] also showed that the silane treatment could double the number of freeze-thaw cycles at which concrete began cracking in fresh water test. Though there is a study have suggested that silane-treated concrete deteriorates more quickly than untreated concrete in laboratory accelerated freeze-thaw tests [90], others have reported that this was not the case in real structures [89, 91]. The effect of silane on freeze-thaw resistance of concrete is influenced by two factors. The first is the concrete initial moisture content. When the concrete is initially dry, the resistance of the silane to the freezing-thawing is very significant. Because the silane can reduce the water ingression into concrete. But when the concrete is saturated before treatment, silane cannot prevent the expansion of freezing capillary water, thus it cannot reduce risk of freeze-thaw damage [8]. Second, its effect will repulsive force provided by silane.

Freeze-thaw damage would be substantially intensified in the presence of deicers used for pavement or bridge maintenance in winter, which is known as salt frost deterioration [9]. A number of studies have found that salt scaling was significantly reduced by the hydrophobic

\subsection{Steel corrosion}


corrosion, and hence the longer service life of the reinforced concrete structure is [56]. Generally, concrete surface treatments could provide protection on reinforce steel corrosion to some extent. Cleland and Basheer [8] found that surface treatments increased the initial time of reinforcement corrosion. Ibrahim et al. [46, 60] studied the effects of various surface treatment methods on the corrosion of steel bars, as shown in Table 4. The effect of silane on steel corrosion is widely investigated, but researchers cannot get agreement. According to Basheer and Ibrahim $[8,46,60]$, the corrosion current reduced by more than one half, and the corrosion by-products reduced by about $50 \%$ after the silane treatment. Sivasankar et al. [95] showed that silane could extend the reinforcement corrosion time by almost 4 times, and this effect was affected by the molecular size of the hydrophobic treatment agent. Vassie et al. [96] reported that the rate of corrosion was reduced by $37 \%$ after alkylalkoxylsilane treatment, though it could not completely prevent the corrosion of steel bars. However, Tittarelli and Moriconi [97] showed silane would accelerate the corrosion on steel bars in cracking concrete though it could significantly reduce the corrosion rate in un-cracking concrete. The reason is that the diffusion rate of oxygen is larger in dry capillary due to silane treatment than that of water-filled pores. The silicone resin solution could only reduce the corrosion current density by a relatively small degree, and sodium silicate almost cannot prevent corrosion of steel bars [46, 60]. Similar results were found by Batias [98] who showed that the silicate inorganic surface treatment agent had limited protection effect in anti-corrosion. Recently, graphite was added into acrylic, chlorinated rubber or epoxide coatings for cathodic protection of reinforced concrete $[99,100]$. The conductive coating have been successfully used in trials and full-scale applications on highway bridges, car parks, and buildings, and can overcome some flaws of classic concrete cathodic protection solutions [100]. In the presence of cracks, hydrophobic agents may cause higher corrosion currents because oxygen diffusion much faster through the unsaturated porosity caused by the hydrophobic agents [101-103. However, only a few research evaluated the anti-corrosion effect of surface treatment on cracked concrete [17].

\section{Durability of surface treatment}

The durability of surface treatments has significant impact on the durability of 
surface-treated concrete, and thus needs more attention. The durability of the surface treatments is influenced by temperature cycle, dry-wet cycle, and radiation etc. [8, 104-106]. In addition, surface treatments should be able to adapt to a variety of work environment, such as wide range of $\mathrm{pH}$, humidity, and substrate temperature (generally -15 to $45^{\circ} \mathrm{C}$ ). Therefore, the researches of durability of surface treatments is summarize in this section.

Researches showed that temperature and ultraviolet radiation highly affected the efficiency of surface treatments. Vries [107] studied resistance of hydrophobic surface treatments, such as silane and siloxane, at the high temperature. The results showed that the water absorption rate for the treated concrete increased dramatically after half-an-hour storage in a $160{ }^{\circ} \mathrm{C}$ chamber. Dhir [48] also found that temperature had a great influence on the resistance to chloride ion permeability of the treated concrete. Although the resistance of silane on the chloride ion was very good at $20{ }^{\circ} \mathrm{C}$, its performance significantly decreased when the temperature was raised up to $45{ }^{\circ} \mathrm{C}$. The main reason is that the hydrophobic capillary wall formed by silane will damage at high temperature, and its waterproof capability decreases. Levi et al. [41] found that protection of silane, silicone and fluorinated polymer on concrete water absorption decreased by 50\%, $90 \%$ and $50 \%$ after ultraviolet aging. Researchers [108-111] found that the $\mathrm{O}-\mathrm{CH}$ bond and $\mathrm{C}-\mathrm{N}$ bond in acrylic coating might break after aging. In epoxy coating, concentration of C-C and C-O groups decreased while the $\mathrm{C}=\mathrm{O}$ and $\mathrm{COO}$ groups increased after aging. Aging also resulted in reduction of the $\mathrm{C}-\mathrm{H}$ and $\mathrm{C}-\mathrm{O}$ in polyurethane coating. But, there is no research showed the effect of temperature and radiation on the performance of acrylic, epoxy, and polyurethane coatings in protecting concrete. Additionally, there are limited research on other factors which might led to treatment aging, and coupled effects of these factors.

Many researchers [55, 58, 112] had studied the long-term effects of the surface treatments in natural environment. However, they showed inconsistent conclusion due to the differentiation of exposure environment and properties of original concrete, Thus it is difficult to compare. According to the concentration of chlorine ions, Schueremans et al. [58] studied the performance of silane treated reinforced concrete samples extracted from the quay wall after 12 years. The study proved that the long-term effect of silane cannot guarantee. Seneviratne et al. [112] believed that the waterproof property of organic surface coating 
would decrease with time in natural environment. The main reason is that the elasticity and viscosity of organic coating will decrease with temperature and time. Moradllo et al. [55] studied performance changes of resistance to chloride ion of a variety of concrete coatings as the time changes. The results turned out that the surface coatings could reduce the diffusion of chloride ions within the first 9 months, but this effect decreased with the time. Even coatings with excellent resistance to chloride ion, its diffusion coefficient would increase after 35 months. But they also showed that the diffusion coefficient of acrylic modified cement based coating concrete exceed of untreated concrete after 5 years, which was consistent with the study of Rodrigues et al. [113]. According to the research of Moraddlo [55], the durability order of resistance to chloride corrosion of surface treatment layer are as follow: fat acrylic < epoxy modified polyurethane < cement based coating < styrene acrylic ester. Li et al. [114] calculated service lives of some organic coating for concrete from the two types of artificially accelerated aging experiments, as shown in Table 5. According to $\mathrm{Li}$, the service life of silane-based water repellent coating was twice as long as that of cement-based coating, and was almost twenty as long as that of epoxy and polyurethane. However, by studying the long-term water absorption of silane immersed concrete, some researchers had found that the silane has enough long-term protective effect. Polder and De Vries [29] found that, after 5 years of outdoor exposure, the silane treatment still had a residual protective effect on the concrete. Christodoulou et al. [115] found that, even after 20 years, the protective effect still existed. The results of Christodoulou's experiment had some fluctuations, and due to the lack of comprehensive meteorological information, these fluctuations have not been well explained.

Once the coating is degraded, the diffusion rate of chloride ion in the surface treated concrete is likely to be greater than that of the untreated concrete, the reasons are as follow. (1) The surface has gathered enough concentrations of chloride ions. (2) Before the failure of coatings, the water is hard to lose due to the treatment, so that the concrete matrix is in the wet state, making chloride ion more easily to intrude. Thus, studies should be performed on the application and aging laws of coatings for concrete structures. To do this, realistic modern weathering tests should be made up. 


\section{Summary and perspective}

Protection of concrete through surface treatment is a complex issue, which includes various physical-chemical mechanisms. The following summarizes the most important conclusions of this paper:

(1) Effects of organic coatings and hydrophobic impregnation on the mechanical properties of concrete have not attracted much attention. But researches did show that silica-based treatment could prevent loss of compressive strength of concrete after being exposed to elevated temperature. Among organic surface treatments, epoxy coating had best abrasion resistance, while silane showed no effect on abrasion protection. Some inorganic treatments were reported to increase abrasion resistance, and their effect has the following order: sodium silicate > ethyl silicate > nano-silica. No research compared the effects organic and inorganic treatments.

(2) Most surface treatments can reduce water permeability of concrete. Within all surface treatments which effect on water absorption have been evaluated, effect of polymer coatings was most significant. Hydrophobic impregnations, such as silane and siloxane, can prevent water ingress without hydrostatic pressure. Some newly developed treatment, such as ethyl silicate and paper sludge ash coating also showed good resistance in water absorption.

(3) In most case, surface treatments can prevent the ingress of aggressive substances. It is widely accepted that polymer coatings are more efficient than other treatment methods in chloride resistance. Addition of nanocomposites could improve effect of traditional polymer coating in chloride resistance. Additionally, the reports on effect of sodium silicate and silane is inconsistent. For carbonation retardation, polymer coatings still showed better effects than other treatment method. Silicate-based treatment has more significant protection than silane and siloxane which hardly prevent the ingress of $\mathrm{CO}_{2}$. Polyurethane was more effective and economical treatment method to prevent sulphate attack. SAR also demonstrated effectiveness in cutting the penetration channel of sulfate. Generally, organic coatings have better resistance than silane based hydrophobic and sodium silicate, while acrylic coating cannot protect concrete against physical sulfate attack due to its brittleness.

(4) Current research mainly focus on protection of silane on freeze-thaw damage, and 
they cannot reach an agreement now. It is proved that epoxy-based sealer and the silane-based water repellent exhibited effect on salt-scaling resistance. Silane can increase the initial time of reinforcement corrosion, and reduce corrosion current in un-cracked concrete, while silicate sodium showed negligible effect on corrosion resistance.

To get a full picture of surface treatment method, the following aspects need to be considered in the future research.

(1) There is a need to conduct a comprehensive investigation to understand the effectiveness of surface coating on the mechanical properties and durability recovery of fire-damaged concretes cooled in the air.

(2) There are no definitive acceptance criteria to evaluate many of the properties discussed in this article, thus it is difficult to compare the performance of various surface treatments.

(3) The performance of inorganic surface treatment and newly developed surface treatment, like polymer/clay nanocomposite coating, modify epoxy resin, need further research to apply these surface treatment agents into practice.

(4) Because of the limited research on the durability of surface treatment, it is very difficult to predict the service life of surface treated concrete. Model taking into account the durability of surface treatments is also needed to develop.

(5) The effect of surface on preventing the corrosion on cracked concrete is still unclear.

\section{Acknowledgement}

Financially supported by the National Science Foundation of China under project Nos. U1305243 and 51378196.

\section{References:}

[1] Wen XD, Tu JL, Gan WZ. Durability protection of the functionally graded structure concrete in the splash zone. Construction and Building Materials 2013; 41:246-51.

[2] Pour-Ali S, Dehghanian C, Kosari A. Corrosion protection of the reinforcing steels in chloride-laden concrete environment through epoxy/polyaniline-camphorsulfonate nanocomposite coating. Corrosion Science 2015; 90:239-247. 
[3] Kreijger PC. The skin of concrete composition and properties. Matériaux et Construction 1984; 17(4): 275-283.

[4] Long AE, Henderson GD, Montgomery FR. Why assess the properties of near-surface concrete? Construction and Building Materials 2001; 15(2):65-79.

[5] Dhir RK, Hewlett PC and Chan YN. Near-surface characteristics of concrete: assessment and development of in situ test methods. Magazine of Concrete Research 1987; 39(141):183-195.

[6] Song H, Lee C and Ann KY. Factors influencing chloride transport in concrete structures exposed to marine environments. Cement and Concrete Composites 2008; 30(2): 113-121.

[7] Meyer A. Importance of the Surface Layer for the Durability of Concrete Structures. ACI Special publication 1987; 100:49-62.

[8] Basheer P, Basheer L, Cleland DJ, Long AE. Surface treatments for concrete: assessmentmethods and reported performance. Construction and Building Materials 1997; 11(7): 413-429.

[9] Delucchi M, Barbucci A and Cerisola G. Study of the physico-chemical properties oforganic coatings for concrete degradation control. Construction and Building Materials 1997; 11(7): 365-371.

[10] Hansson CM, Mammoliti L, Hope BB. Corrosion inhibitors in concrete-part I: the principles. Cement and concrete research 1998; 28(12):1775-1781.

[11] Franzoni E, Pigino B, Pistolesi C. Ethyl silicate for surface protection of concrete: Performance in comparison with other inorganic surface treatments. Cement and Concrete Composites 2013; 44(0):69-76.

[12] Pacheco-Torgal F, Jalali S. Sulphuric acid resistance of plain, polymer modified, and fly ash cement concretes. Construction and Building Materials 2009; 23(12):3485-3491.

[13] Medeiros M, Helene P. Efficacy of surface hydrophobic agents in reducing water and chloride ion penetration in concrete. Materials and Structures 2008; 41(1):59-71.

[14] Diamanti MV, Brenna A, Bolzoni F, Berra M, Pastore T, Ormellese M. Effect of polymer modified cementitious coatings on water and chloride permeability in concrete. Construction and Building Materials 2013; 49(0):720-728.

[15] Bertolini L, Elsener B, Pedeferri P, Redaelli E, Polder RB. Corrosion of steel in concrete: 
prevention, diagnosis, repair. 2013: John Wiley \& Sons.

[16] Woo RS, Zhu H, Chow MM, Leung CK, Kim J. Barrier performance of silane-clay nanocomposite coatings on concrete structure. Composites science and technology 2008; 68(14):2828-2836.

[17] Dai J, Akira Y, Wittmann FH, Yokota H, Zhang P. Water repellent surface impregnation for extension of service life of reinforced concrete structures in marine environments: the role of cracks. Cement and Concrete Composites 2010; 32(2):101-109.

[18] Moon HY, Shin DG, Choi DS. Evaluation of the durability of mortar and concrete applied with inorganic coating material and surface treatment system. Construction and Building Materials 2007; 21(2): 362-369.

[19] Pan X, Shi C, Jia L, Zhang J, Wu L. Effect of Inorganic Surface Treatment on Air Permeability of Cement-Based Materials. Journal of Materials in Civil Engineering 2015: 04015145 .

[20] Leung CK, Zhu H, Kim J, Woo RS. Use of polymer/organoclay nanocomposite surface treatment as water/ion barrier for concrete. Journal of materials in civil engineering 2008; 20(7):484-492.

[21] Pan X, Shi Z, Shi C, Li N. A review on concrete surface treatment Part I: types and mechanisms.

[22] Li Q, Li Z, Yuan G, Shu, Q. The effect of a proprietary inorganic coating on compressive strength and carbonation depth of simulated fire-damaged concrete. Magazine of Concrete Research, 2013, 65(11): 651-659.

[23] Yuan G, Li Q. The use of surface coating in enhancing the mechanical properties and durability of concrete exposed to elevated temperature. Construction and Building Materials 2015; 95:375-383.

[24] Toutanji HA, Choi H, Wong D, Gilbert JA, Alldredge DJ. Applying a polyurea coating to high-performance organic cementitious materials. Construction and Building Materials 2013; 38:1170-1179.

[25] Jia L, Shi C, Pan X, Zhang J, Wu L. Effects of inorganic surface treatment on water permeability of cement-based materials, Cement and Concrete Composites 2016; 67:85-92.

[26] Baltazar L, Santana J, Lopes B, Paula Rodrigues M, Correia JR. Surface skin protection 
of concrete with silicate-based impregnations: Influence of the substrate roughness and moisture. Construction and Building Materials 2014; 70(0):191-200.

[27] Dang Y, Xie N, Kessel A, McVey E, Pace A, Shi X. Accelerated laboratory evaluation of surface treatments for protecting concrete bridge decks from salt scaling. Construction and Building Materials 2014; 55(0):128-135.[28] Shi L, Liu J, Liu J, Effect of polymer coating on the properties of surface layer concrete. Procedia Engineering-2011 Chinese Materials Conference 2012; 27(0):291-300.

[29] Aguiar JL, Camões A, Moreira P. Performance of concrete in aggressive environment. Journal of Concrete Structures and Materials 2008; 2(1):21-25.

[30] Almusallam AA, Khan FM, Dulaijan SU, Al-Amoudi O. Effectiveness of surface coatings in improving concrete durability. Cement and Concrete Composites 2003; 25(4):473-481.

[31] Swamy RN, Suryavanshi AK, Tanikawa S. Protective ability of an acrylic-based surface coating system against chloride and carbonation penetration into concrete. ACI Materials Journal 1998; 95(2):101-112.[32] Mehta PK, Monteiro PJ, Concrete: microstructure, properties, and materials. Vol. 3. 2006: McGraw-Hill New York.

[33] Attanayake U, Liang X, Ng S, Aktan H. Penetrating sealants for concrete bridge decks—selection procedure. Journal of Bridge Engineering 2006; 11(5):533-540.

[34] Pfeifer DW, Scali MJ. Concrete sealers for protection of bridge structures. NCHRP report 244. Transport Research Board, National Research Council, 1981.

[35] Pigino B, Leemann A, Franzoni E, Lura P. Ethyl silicate for surface treatment of concrete-Part II: Characteristics and performance. Cement and Concrete Composites 2012; 34(3):313-321.

[36] Medeiros MH, Helene P. Surface treatment of reinforced concrete in marine environment: Influence on chloride diffusion coefficient and capillary water absorption. Construction and building materials 2009; 23(3):1476-84.

[37] Franzoni E, Varum H, Natali ME, Bignozzi MC, Melo J, Rocha L, Pereira E. Improvement of historic reinforced concrete/mortars by impregnation and electrochemical methods. Cement and Concrete Composites 2014; 49(0):50-58.

[38] Hou P, Cheng X, Qian J, Shah SP. Effects and mechanisms of surface treatment of 
578 hardened cement-based materials with colloidal nanoSiO 2 and its precursor. Construction and 579 Building Materials 2014; 53(0): 66-73.

580 [39] De Muynck W, Cox K, De Belie N, Verstraete W. Bacterial carbonate precipitation as an

581

582

583

584

585

586

587

588

589

590

591

592

593

594

595

596

597

598

599

600

601

602

603

604

605

606

607 alternative surface treatment for concrete. Construction and Building Materials 2008; 22(5):875-885.

[40] Wong HS, Barakat R, Alhilali A, Saleh M, Cheeseman CR. Hydrophobic concrete using waste paper sludge ash. Cement and Concrete Research 2015; 70:9-20.

[41] Levi M, Ferro C, Regazzoli D, Dotelli G, Lo Presti A. Comparative evaluation method of polymer surface treatments applied on high performance concrete. Journal of Materials Science 2002; 37(22):4881-4888.

[42] Weisheit S, Unterberger SH, Bader T, Lackner R. Assessment of test methods for characterizing the hydrophobic nature of surface-treated High Performance Concrete. Construction and Building Materials, 2016, 110: 145-153.

[43] Nilsson LO, Ollivier JP. Chloride transport due to wick action in concrete. in RILEM international workshop on chloride penetration into concrete. 1995: RILEM Publications SARL.

[44] Buenfeld NR, Zhang J, Chloride diffusion through surface-treated mortar specimens. Cement and concrete Research 1998; 28(5):665-674.

[45] Climent MA, de Vera G, López JF, López JF, Viqueira E. A test method for measuring chloride diffusion coefficients through nonsaturated concrete: Part I. The instantaneous plane source diffusion case. Cement and concrete Research, 2002, 32(7): 1113-1123.

[46] Ibrahim M, Al-Gahtani AS, Maslehuddin M, Dakhil FH. Use of surface treatment materials to improve concrete durability. Journal of materials in civil engineering 1999; 11(1):36-40.

[47] Brenna A, Bolzoni F, Beretta S, Ormellese M. Long-term chloride-induced corrosion monitoring of reinforced concrete coated with commercial polymer-modified mortar and polymeric coatings. Construction and Building Materials 2013; 48:734-744.

[48] Jones MR, Dhir RK, Gill JP. Concrete surface treatment: effect of exposure temperature on chloride diffusion resistance. Cement and Concrete Research 1995; 25(1):197-208.

[49] De Muynck W, Debrouwer D, De Belie N, Verstraete W. Bacterial carbonate 
precipitation improves the durability of cementitious materials. Cement and concrete Research, 2008, 38(7): 1005-1014.

[50] Pritzl MD, Tabatabai H, Ghorbanpoor A. Long-term chloride profiles in bridge decks treated with penetrating sealer or corrosion inhibitors. Construction and Building Materials 2015; 101:1037-1046.

[51] Yang CC, Wang LC and Weng TL. Using charge passed and total chloride content to assess the effect of penetrating silane sealer on the transport properties of concrete. Materials chemistry and physics 2004; 85(1): 238-244.

[52] Shi X, Xie N, Fortune K, Gong J. Durability of steel reinforced concrete in chloride environments: An overview. Construction and Building Materials 2012; 30:125-138.

[53] Buenfeld NR, Newman JB. Examination of three methods for studying ion diffusion in cement pastes, mortars and concrete. Materials and Structures 1987; 20(1):3-10.

[54] He F, Shi C, Yuan Q, Chen C, Zheng K. AgNO 3 -based colorimetric methods for measurement of chloride penetration in concrete. Construction and Building Materials 2012; 26(1):1-8.

[55] Khanzadeh Moradllo M, Shekarchi M, Hoseini M. Time-dependent performance of concrete surface coatings in tidal zone of marine environment. Construction and Building Materials 2012; 30:198-205.

[56] Petcherdchoo A. Pseudo-coating model for predicting chloride diffusion into surface-coated concrete in tidal zone: Time-dependent approach. Cement and Concrete Composites, 2016, 74: 88-99.

[57] Zhang J, McLoughlin IM, Buenfeld NR. Modelling of chloride diffusion into surface-treated concrete. Cement and Concrete Composites 1998; 20(4):253-261.

[58] Schueremans L, Van Gemert D, Giessler S. Chloride penetration in RC-structures in marine environment-long term assessment of a preventive hydrophobic treatment. Construction and Building Materials 2007; 21(6):1238-1249.

[59] Andrade C, Díez JM, Alonso C. Mathematical modeling of a concrete surface "skin effect" on diffusion in chloride contaminated media. Advanced Cement Based Materials 1997; 6(2):39-44.

[60] Ibrahim M, Al-Gahtani AS, Maslehuddin M, Almusallam AA. Effectiveness of concrete 
surface treatment materials in reducing chloride-induced reinforcement corrosion. Construction and Building Materials 1997; 11(7-8):443-451.

[61] Ann KY, Ahn JH, Ryou JS. The importance of chloride content at the concrete surface in assessing the time to corrosion of steel in concrete structures. Construction and building materials 2009; 23(1):239-245.

[62] Papadakis VG. Effect of supplementary cementing materials on concrete resistance against carbonation and chloride ingress. Cement and concrete research 2000; 30(2):291-299. [63] Glasser FP, Marchand J, Samson E. Durability of concrete-degradation phenomena involving detrimental chemical reactions, Cement and Concrete Research 2008; 38(2):226-246.

[64] Chi JM, Huang R, Yang CC. Effects of carbonation on mechanical properties and durability of concrete using accelerated testing method. Journal of marine science and technology 2002; 10(1):14-20.

[65] Johannesson B, Utgenannt P. Microstructural changes caused by carbonation of cement mortar. Cement and concrete Research 2001; 31(6):925-931.

[66] Papadakis VG, Vayenas CG, Fardis MN. Fundamental modeling and experimental investigation of concrete carbonation. ACI materials journal 1991; 88(4):363-373.

[67] Chang C, Chen J. The experimental investigation of concrete carbonation depth. Cement and Concrete Research 2006; 36(9):1760-1767.

[68] Jiang L, Lin B, Cai Y. A model for predicting carbonation of high-volume fly ash concrete. Cement and Concrete Research 2000; 30(5):699-702.

[69] Aguiar JB, Júnior C. Carbonation of surface protected concrete. Construction and Building Materials 2013; 49:478-483.

[70] Zhu Y, Kou S, Poon C, Dai J, Li Q. Influence of silane-based water repellent on the durability properties of recycled aggregate concrete. Cement and Concrete Composites 2013; 35(1):32-38.

[71] Park DC. Carbonation of concrete in relation to $\mathrm{CO}_{2}$ permeability and degradation of coatings. Construction and building Materials 2008; 22(11):2260-2268.

[72] Song H, Kwon S. Permeability characteristics of carbonated concrete considering capillary pore structure. Cement and Concrete Research 2007; 37(6):909-915. 
668

669

670

671

672

673

674

675

676

677

678

679

680

681

682

683

684

685

686

687

688

689

690

691

692

693

694

695

696

697

[73] Berndt ML. Evaluation of coatings, mortars and mix design for protection of concrete against sulphur oxidising bacteria. Construction and Building Materials 2011; 25(10):3893-3902.

[74] Khatri RP, Sirivivatnanon V, Yang JL. Role of permeability in sulphate attack. Cement and concrete research 1997; 27(8):1179-1189.

[75] Redner J. Evaluating Protective Coatings for Concrete Exposed to Sulfide Generation in Wastewater Treatment Facilities. Journal of Protective Coatings \& Linings 1991; 8(11):48-56.

[76] Redner J. Evaluating Coatings for Concrete in Waste Water Facilities: An Update. Journal of Protective Coatings \& Linings 1994; 11(12):50-61.

[77] Vipulanandan C, Liu J. Glass-fiber mat-reinforced epoxy coating for concrete in sulfuric acid environment. Cement and Concrete Research, 2002, 32(2): 205-210.

[78] Nia SM, Othman F. Evaluation of Organic Coating Materials Efficiency in Sewage Concrete Pipe. Proceeding of the International Conference for Technical Postgraduates (TECHPOS 2009), Kuala Lumpur, Malaysia. 2009.

[79] Song XF, Wei JF, He TS. A novel method to improve sulfate resistance of concrete by surface treatment with super-absorbent resin synthesised in situ. Magazine of Concrete Research 2008; 60(1):49-55.

[80] Suleiman AR, Soliman AM, Nehdi ML. Effect of surface treatment on durability of concrete exposed to physical sulfate attack. Construction and Building Materials 2014; 73:674-681.

[81]Price AR, A field trial of waterproofing systems for concrete bridge decks. Proceedings of the International Conference, United Kingdom, 1989, 333-346.

[82] Radlinska A, Yost J, McCarthy L, Matzke J, Nagel F. Coatings and Treatments for Beam Ends. 2012.

[83] De Muynck W, De Belie N, Verstraete W. Effectiveness of admixtures, surface treatments and antimicrobial compounds against biogenic sulfuric acid corrosion of concrete. Cement and Concrete Composites 2009; 31(3):163-170.

[84] Vaidya S, Allouche EN. Electrokinetically deposited coating for increasing the service life of partially deteriorated concrete sewers. Construction and Building Materials 2010; 24(11): 2164-2170. 
[85] Vipulanandan C, Liu J. Performance of polyurethane-coated concrete in sewer environment. Cement and Concrete Research 2005; 35(9):1754-1763.

[86] Vipulanandan C, Liu J. Film model for coated cement concrete. Cement and Concrete Research 2002; 32(12):1931-1936.

[87] Liu J, Vipulanandan C. Modeling water and sulfuric acid transport through coated cement concrete. Journal of engineering mechanics 2003; 129(4):426-437.

[88] Liu J, Vipulanandan C. Evaluating a polymer concrete coating for protecting non-metallic underground facilities from sulfuric acid attack. Tunnelling and Underground Space Technology 2001; 16(4):311-321.

[89] Basheer L, Cleland DJ. Freeze-thaw resistance of concretes treated with pore liners. Construction and Building Materials 2006; 20(10): 990-998.

[90] Perenchio WF. Durability of concrete treated with silanes. Concrete international, 1988. 10(11): 34-40.

[91] Pigeon M, Prevost J and Simard J, Freeze-thaw durability versus freezing rate. Journal of the American Concrete Institute, 1985. 82(5): 684-692.

[92] Mamaghani I, Moretti C, Dockter B, Falken L, Tonnenson J. Evaluation of penetrating sealers for reinforced concrete bridge decks. Transportation Research Record: Journal of the Transportation Research Board 2009; (2108): 86-96.

[93] Hazrati K, Abesque C, Pigeon M, Sedran, T. Efficiency of sealers on the scaling resistance of concrete in presence of deicing salts. RILEM Proceedings 30. Freeze-Thaw Durability of Concrete, 1997.

[94] Liu Z, Hansen W. Effect of hydrophobic surface treatment on freeze-thaw durability of concrete. Cement and Concrete Composites, 2016, 69: 49-60.

[95] Sivasankar A, Arul Xavier Stango S, Vedalakshmi R. Quantitative estimation on delaying of onset of corrosion of rebar in surface treated concrete using sealers. Ain Shams Engineering Journal 2013; 4(4):615-623.

[96] Vassie PR. Concrete coatings: do they reduce ongoing corrosion of reinforcing steel? Corrosion of reinforcement in concrete, 1990: 456-470.

[97] Tittarelli F, Moriconi G. The effect of silane-based hydrophobic admixture on corrosion of galvanized reinforcing steel in concrete. Corrosion Science 2010; 52(9):2958-2963. 
[98] Batis G, Pantazopoulou P, Routoulas A. Corrosion protection investigation of reinforcement by inorganic coating in the presence of alkanolamine-based inhibitor. Cement and Concrete Composites 2003; 25(3):371-377.

[99] Orlikowski J, Cebulski S, Darowicki K. Electrochemical investigations of conductive coatings applied as anodes in cathodic protection of reinforced concrete. Cement and Concrete Composites 2004; 26(6):721-728.

[100] Page CL, Sergi G. Developments in cathodic protection applied to reinforced concrete. Journal of Materials in civil engineering 2000; 12(1):8-15. [101] Tittarelli F. Oxygen diffusion through hydrophobic cement-based materials. Cement and Concrete Research 2009; 39(10): 924-928.

[102] Tittarelli F, Moriconi G. The effect of silane-based hydrophobic admixture on corrosion of reinforcing steel in concrete. Cement and Concrete Research 2008; 38(11):1354-1357.

[103] Tittarelli F, Moriconi G. Comparison between surface and bulk hydrophobic treatment against corrosion of galvanized reinforcing steel in concrete. Cement and Concrete Research 2011; 41(6):609-614.

[104] Eymard M, Plassiard J, Perrotin P, Le Fay S. Interfacial strength study between a concrete substrate and an innovative sprayed coating. Construction and Building Materials $2015 ; 79: 345-356$.

[105] Li G, Yang B, Guo C, Du J, Wu X. Time dependence and service life prediction of chloride resistance of concrete coatings. Construction and Building Materials 2015; 83:19-25. [106] Kozak A. Multi-criteria assessment of an acrylic coating exposed to natural and artificial weathering. Procedia Engineering 2015; 108: 664-672.

[107] De Vries IJ, Polder RB. Hydrophobic treatment of concrete. Construction and building materials 1997; 11(4): 259-265.

[108] Reddy B, Sykes JM. Degradation of organic coatings in a corrosive environment: a study by scanning Kelvin probe and scanning acoustic microscope, Progress in organic coatings 2005; 52(4):280-287.

[109] Yang XF, Vang C, Tallman DE, Bierwagen GP, Croll SG, Rohlik S. Weathering degradation of a polyurethane coating. Polymer degradation and stability 2001; 74(2):341-51. [110] Kotnarowska D. Influence of ultraviolet radiation and aggressive media on epoxy 
758 coating degradation. Progress in Organic Coatings 1999; 37(3):149-59.

759 [111] Al-Turaif HA. Surface morphology and chemistry of epoxy-based coatings after 760 exposure to ultraviolet radiation. Progress in Organic Coatings. 2013; 76(4):677-81.

761 [112] Seneviratne AMG, Sergi G, Page CL. Performance characteristics of surface coatings 762 applied to concrete for control of reinforcement corrosion. Construction and Building 763 Materials 2000; 14(1):55-59.

764 [113] Rodrigues M, Costa M, Mendes AM, Marques ME. Effectiveness of surface coatings to 765 protect reinforced concrete in marine environments. Materials and Structures 2000; $766 \quad 33(10): 618-626$.

767 [114] Li G, Yang B, Guo C, Du J, Wu X. Time dependence and service life prediction of 768 chloride resistance of concrete coatings. Construction and Building Materials, 2015. 83: $769 \quad 19-25$.

770 [115] Christodoulou C, Goodier CI, Austin SA, Webb J, Glass GK. Long-term performance of 771 surface impregnation of reinforced concrete structures with silane. Construction and Building 772 Materials 2013; 48(0): 708-716. 
LIST OF TABLES

781

782 Table 1 Effect of surface treatment on water absorption of concrete.

783 Table 2 Effect of surface treatment on chloride penetration.

784 Table 3 Effect of surface treatments on carbonation.

785 Table 4 Effect of surface treatment on steel corrosion.

786 Table 5 Service-life prediction of coatings under natural environment.

787 


\begin{tabular}{|c|c|c|c|}
\hline Ref. & Surface treatment & $\begin{array}{l}\text { Relative water } \\
\text { absorption }\end{array}$ & comment \\
\hline$[30]$ & $\begin{array}{l}\text { polymer emulsion } \\
\text { coating }\end{array}$ & 0.67 & - \\
\hline$[30]$ & acrylic & $0.05-0.29$ & - \\
\hline$[30]$ & chlorinated rubber & $0.15-0.21$ & - \\
\hline$[30]$ & epoxy resin & $0.05-0.26$ & - \\
\hline [35-38] & ethyl silicate & $0.21-0.73$ & $\begin{array}{l}\text { More effective in highly hydrated } \\
\text { cement; no failure in high temperature }\end{array}$ \\
\hline $\begin{array}{l}{[37,} \\
38]\end{array}$ & sodium silicate & $0.67-0.38$ & - \\
\hline$[38]$ & nano-silica & 0.9 & $\begin{array}{l}\text { Its effect can be more significant after } \\
\text { high temperature curing. }\end{array}$ \\
\hline$[25]$ & magnesium fluosilicate & 0.5 & It works mainly at early ages \\
\hline [39] & $\begin{array}{l}\text { bacterial carbonate } \\
\text { precipitation }\end{array}$ & $0.8-0.5$ & $\begin{array}{c}\text { Additional decrease of the permeability } \\
\text { after second time treatment }\end{array}$ \\
\hline [14] & $\begin{array}{l}\text { modified cementitious } \\
\text { mortar coating }\end{array}$ & 0.5 & $\begin{array}{l}\text { Water absorption increase with the } \\
\text { decrease polymer/cement ratio }\end{array}$ \\
\hline$[40]$ & $\begin{array}{l}\text { super-hydrophobic paper } \\
\text { sludge ash coating }\end{array}$ & $0.2-0.14$ & $\begin{array}{l}\text { Coatings of the super-hydrophobic } \\
\text { PSA and cyanoacrylate or epoxy resin } \\
\text { are the most effective }\end{array}$ \\
\hline [41] & silane & 0.2 & $\begin{array}{l}\text { failure when water pressure is higher } \\
\text { than } 120 \mathrm{kgf} / \mathrm{m}^{2}\end{array}$ \\
\hline$[40]$ & siloxane & 0.2 & $\begin{array}{l}\text { failure when water pressure is higher } \\
\text { than } 120 \mathrm{kgf} / \mathrm{m}^{2}\end{array}$ \\
\hline [41] & fluorinated polymer & 0.33 & - \\
\hline
\end{tabular}


Table 2 Effect of surface treatment on chloride penetration.

\begin{tabular}{lccc}
\hline Ref. & Surface treatment & Test methods & Results \\
\hline [18] & Calcium silicate & Guidelines proposed by Japanese & Content of chloride reduced by \\
& & Road Association & $67 \%-80 \%$ \\
\hline & Sodium silicate & The chloride diffusion coefficients & $20.6 \times 10^{-8} \mathrm{~cm}^{2} / \mathrm{s}$ \\
& Silicone resin & were calculated after exposing to & $16.86 \times 10^{-8} \mathrm{~cm}^{2} / \mathrm{s}$ \\
& Silane/siloxane & $5 \%$ NaCl solution at $40^{\circ} \mathrm{C}($ chloride & $14.83 \times 10^{-8} \mathrm{~cm}^{2} / \mathrm{s}$ \\
& Silane/siloxane with an & diffusion of untreated concrete was & $7.83 \times 10^{-8} \mathrm{~cm}^{2} / \mathrm{s}$ \\
& & $\left.21.83 \times 10^{-8} \mathrm{~cm}^{2} / \mathrm{s}\right)$ & \\
& &
\end{tabular}

Polymer emulsion

coating

Acrylic coating

[30] Chlorinated rubber coating

Epoxy coating

Polyurethane coating
ASTM C1202 (chloride diffusion of

untreated concrete was $19.18 \times 10^{-8}$

$$
\mathrm{cm}^{2} / \mathrm{s} \text { ) }
$$

$8.4 \times 10^{-8} \sim 16 \times 10^{-8} \mathrm{~cm}^{2} / \mathrm{s}$

$2.1 \times 10^{-8} \sim 3.5 \times 10^{-8} \mathrm{~cm}^{2} / \mathrm{s}$

$8.4 \times 10^{-8} \sim 9.6 \times 10^{-8} \mathrm{~cm}^{2} / \mathrm{s}$

$2.6 \times 10^{-8} \sim 7.7 \times 10^{-8} \mathrm{~cm}^{2} / \mathrm{s}$

$0.7 \times 10^{-8} \sim 1.8 \times 10^{-8} \mathrm{~cm}^{2} / \mathrm{s}$.

\begin{tabular}{|c|c|c|c|}
\hline \multirow{3}{*}{ [43] } & Acrylic sealer & Stationary chloride diffusion cell & $3.3 \times 10^{-12} \mathrm{~cm}^{2} / \mathrm{s}$ \\
\hline & Polyurethane sealer & $\begin{array}{l}\text { testing (chloride diffusion of } \\
\text { untreated concrete was }\end{array}$ & $0.58 \times 10^{-12} \mathrm{~cm}^{2} / \mathrm{s}$ \\
\hline & Alkylakoxysilane & $\left.3 \times 10^{-12} \mathrm{~cm}^{2} / \mathrm{s}\right)$ & $0.58 \times 10^{-12} \mathrm{~cm}^{2} / \mathrm{s}$ \\
\hline
\end{tabular}

Ethyl silicate

chloride migration depth reduced by

$$
52-62 \%
$$

chloride migration depth reduced by

[11]

Nanosilica

Swiss standard SIA 262/1

$$
20-28 \%
$$

chloride migration depth reduced by

Sodium silicate

$30-50 \%$

[14] Polymer modified Stationary chloride diffusion cell $\quad 0.3 \times 10^{-8} \mathrm{~cm}^{2} / \mathrm{s}-0.8 \times 10^{-8} \mathrm{~cm}^{2} / \mathrm{s}$




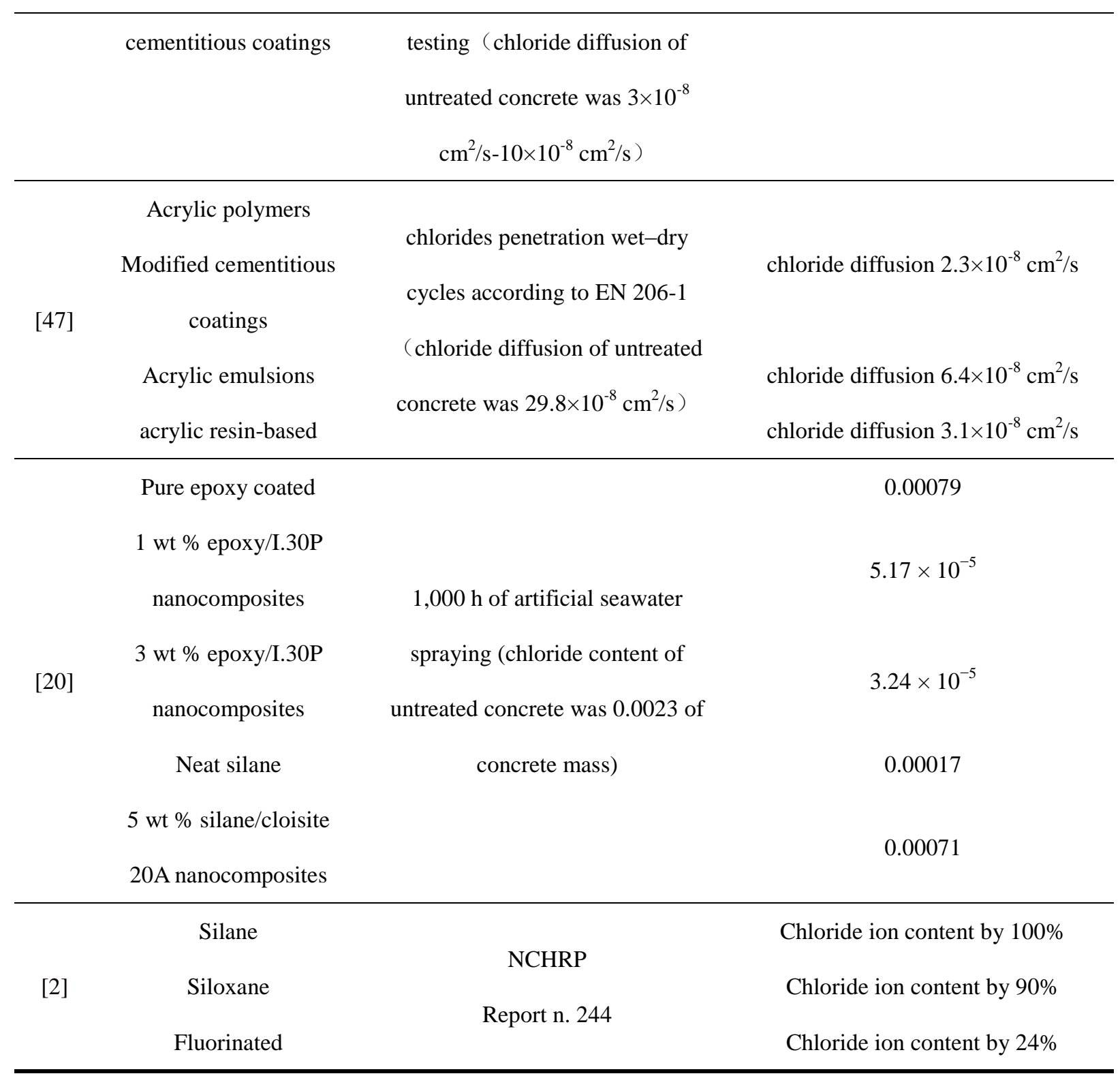


Table 3 Effect of surface treatments on carbonation.

\begin{tabular}{cccc}
\hline Ref. & Surface treatment & $\begin{array}{c}\text { Effect on carbonation } \\
\text { depth }\end{array}$ & comments \\
\hline$[18]$ & calcium silicate & reduce by $26 \% \sim 53 \%$ & - \\
{$[11,46]$} & sodium silicate & reduce by $60 \%-90 \%$ & Limited long term effect \\
{$[46]$} & silane / siloxane & reduce by about 20\% & - \\
{$[46]$} & silicone resin & reduce by about $20 \%$ & - \\
{$[46]$} & silane / siloxane+ acrylic & reduce by almost 100\% & The acrylic top coat play \\
{$[35,46]$} & Two component acrylic & reduce by almost 100\% & - \\
{$[11]$} & ethyl silicate & reduce by $40 \% \sim 80 \%$ & Good long-term effect \\
{$[11]$} & nano-silica & reduce by $14 \% \sim 47 \%$ & - \\
\hline
\end{tabular}


Table 4 Effect of surface treatment on steel corrosion [60].

\begin{tabular}{cccc}
\hline Surface treatment & $\begin{array}{c}\text { Time to initiation of } \\
\text { reinforcement } \\
\text { corrosion (days) }\end{array}$ & $\begin{array}{c}\text { Corrosion current } \\
\text { density }\left(\mu \mathrm{A} / \mathrm{cm}^{2}\right)\end{array}$ & Time to cracking (h) \\
\hline None & 10 & 0.328 & 144 \\
Sodium silicate & 12 & 0.286 & 176 \\
Silicone resin & 40 & 0.31 & 672 \\
solution & 55 & 0.193 & 2125 \\
Silane/siloxane & 340 & 0.0058 & No cracks \\
Silane & 225 & 0.0061 & No cracks \\
Acrylic coating & 320 & 0.0108 & No cracks \\
Silane/siloxane with & & & \\
\hline top coat & & & \\
\hline
\end{tabular}



Table 5 Service-life prediction of coatings under natural environment [113].

\begin{tabular}{lc}
\hline Coating & Predicted service life/y \\
\hline epoxy glass-flake paint & 3.7 \\
polyurethane paint & 3.8 \\
cement-based waterproof coating & 43 \\
silane-based water repellent coating & 77 \\
\hline
\end{tabular}


Fig. 1. Shrinkage ratio of mortar coated with polymer with different thicknesses (a) and various coating time (b).

812 Fig. 2. The relationship between w/c and total amount of chloride with different coverage rate 813 of silane.

814 Fig. 3. Water soluble chloride profiles of untreated and silane-treated concrete. 


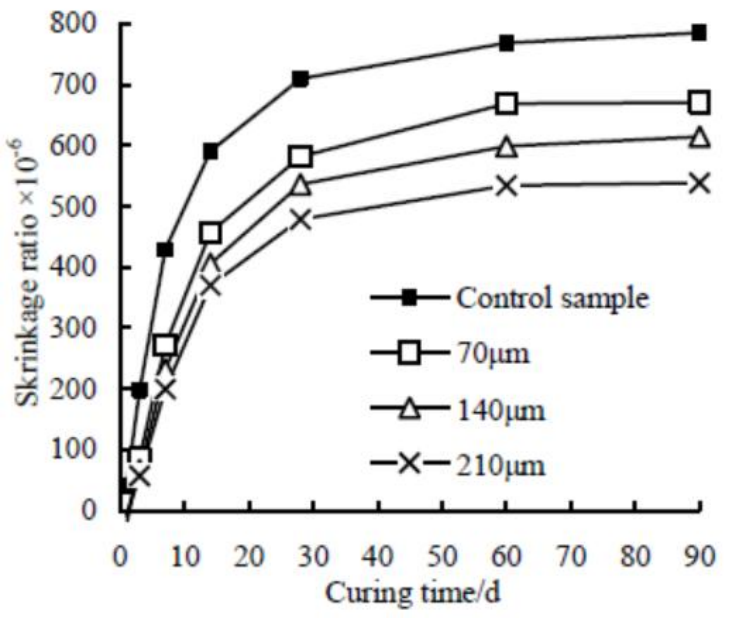

(a)

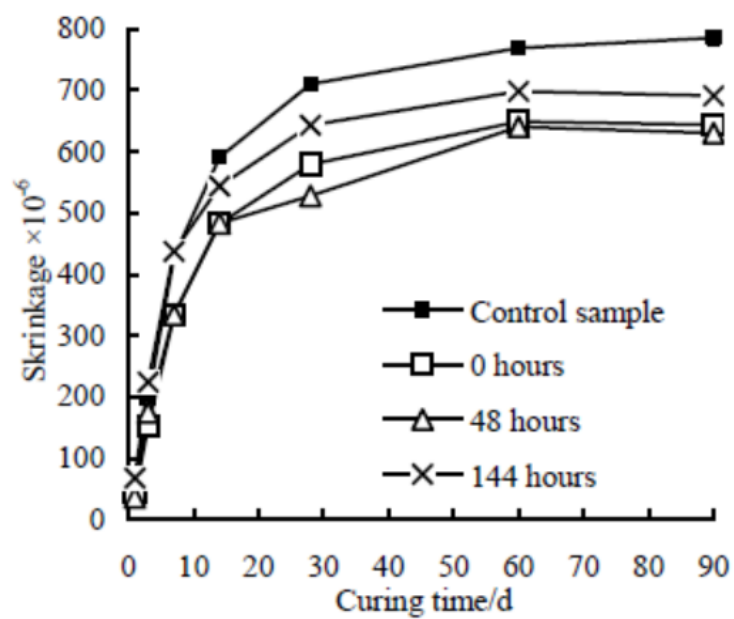

(b)

Fig. 1. Shrinkage ratio of mortar coated with polymer with different thicknesses (a) and various coating time (b) [28]. 


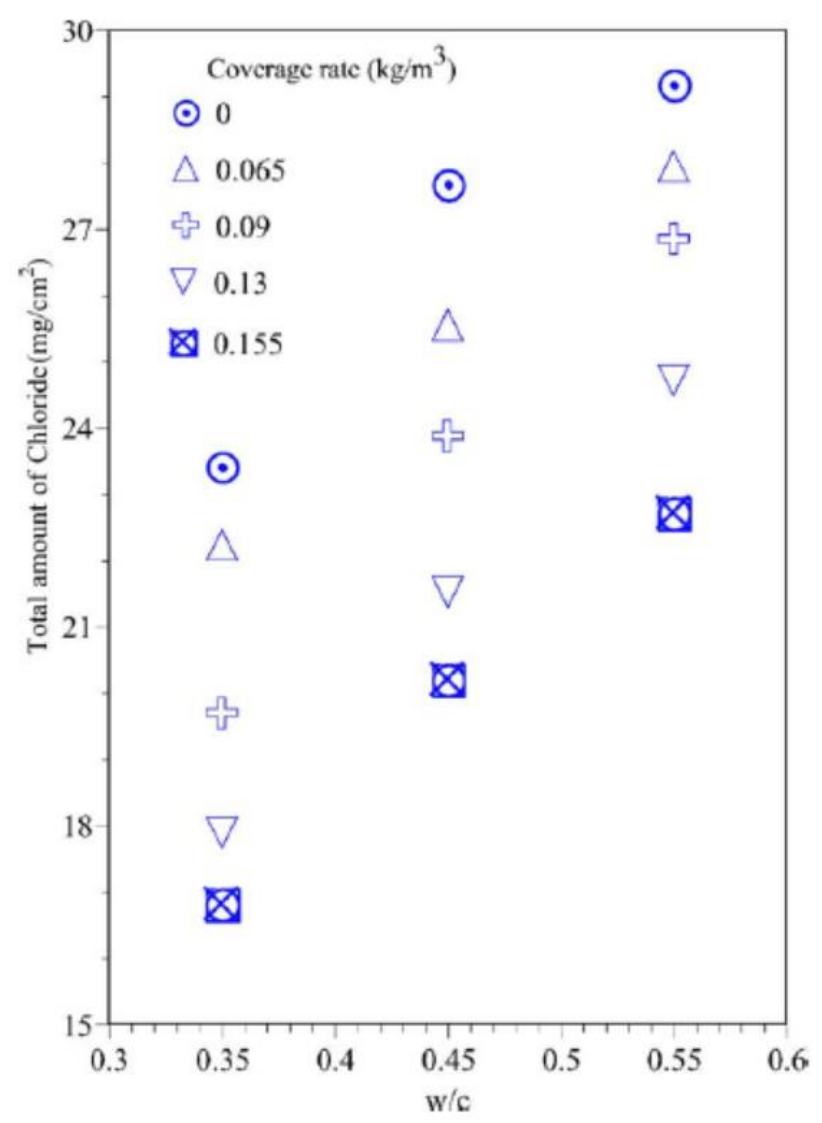

824

Fig. 2. The relationship between w/c and total amount of chloride with different dosage of 825 silane [51]. 


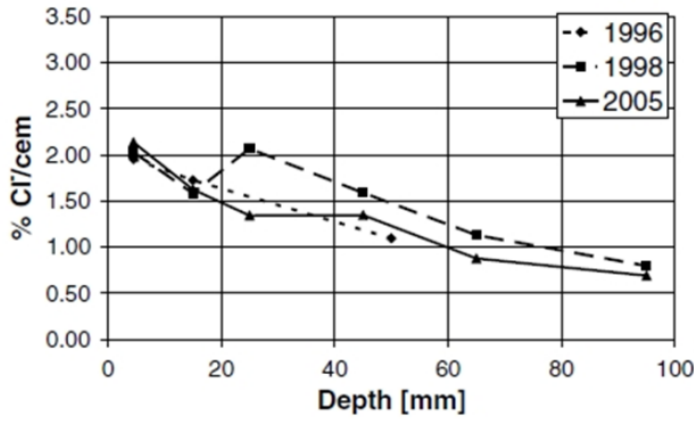

(a) Water soluble chloride content non-treated-in tidalzone

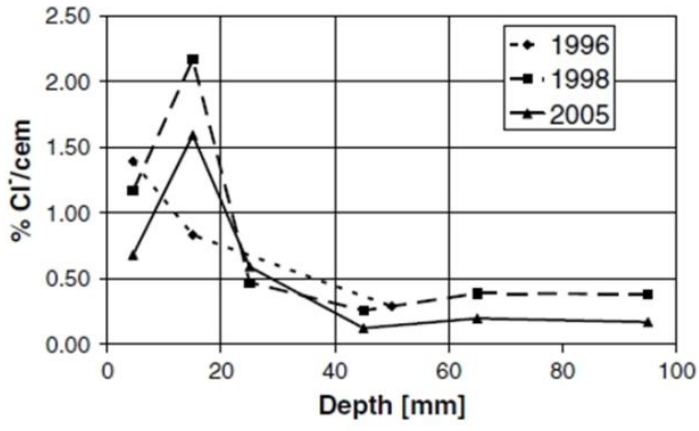

(b) Water soluble chloride content- treated with alkyltriethoxysilane-in tidal zone

Fig. 3. Water soluble chloride profiles of untreated and silane-treated concrete [58]. 